\title{
RESOURCE-BASED COMMERCIAL FISHERIES MANAGEMENT IN EASTERN INDONESIA
}

\author{
Soepanto*
}

\section{BACKGROUND}

Management may be defined as a way or strategy to attain set objectives. It is a system by which people are organized to meet certain purposes. Aside from people as the central element of management, there are also things, alive and dead, which are used in order to arrive at the set objectives. Live things are natural resources usually used as input factors, while dead things are tools or equipment. Management as a system consists of sub-systems. Though there are various different breakdowns of management sub-systems, four that are commonly used are planning, organizing, actuating, and controlling.

A commercial fishery has a set of objectives, looking from producers, consumers, traders, and government viewpoints. The producers are fishers who want to have better landings and income. The objective of consumers could be simply in the form of having enough fish to eat. Traders usually want to have more money, while government objectives are to generate the income needed to run its tasks, duties, and functions. Therefore management of a commercial fishery is not that easy. While the consumers want to have cheap fish and hence expect excess market supply, traders may try to maintain higher prices. In a similar manner, government may set up the fishery to be sustainable in the long run so that it can serve the coming generation. Conversely, the existing fishers could have a short-term strategy to exploit fish resources as much as they can. Hence, management of a commercial fishery may entail conflicts among its beneficiaries.

Since commercial fishing has an economic orientation, it should be a profitable business. In other words, commercial fishing should be properly managed in such a way that the business results in economic rents. Two common ways to generate economic rents are to reduce costs and increase revenues. An increase in revenue may be realised by taking as many fish as possible. How. ever, this is not wise from marine biological and environmental perspectives. Fish resources are susceptible to excess fishing. Therefore fishing should be properly managed and the management of fishing is essentially a resource management question.

Resource management and fishery business management are interrelated. One may have sound resource management that sustains long term resource availability. However. it may not bring about expected benefits if business is weakly managed. On the other hand, business may be accurately designed to generate high profit. Yet if resources are depleted because of excessive fishing, then profitable business may not be sustained. Based on this interrelationship, it may be said that the management of fish resources and the management of a fishing company could be portrayed as a coin with two sides, where neither can be left behind. Both aspects should be considered in developing a commercial fishery. In other words, to have a profitable commercial fishery, the activity must be based on fish resource availability.

This paper attempts to describe the relationship between fish resources and business management that provides long term benefits. A modest term normally used for this relationship is "resource-based commercial fishery management". The experience of P.T. Usaha Mina (henceforth Usaha Mina) in developing small-scale commercial fishing is used as an example in this paper. Based on the experience of Usaha Mina, implications for the development of small-scale commercial fishing in eastern waters of Indonesia are discussed.

\section{FISHERIES IN EASTERN INDONESIA}

Eastern Indonesia refers to the provinces or areas in east Indonesia consisting of Bali, Nusa Tenggara, East Kalimantan, Sulawesi, Maluku, and Irian Jaya. In total, eastern Indonesia comprises 11 provinces. The waters bordered by these provinces are Makasar Strait, Flores Sea, Maluku Sea, Sulawesi Sea, Halmahera Sea, Banda Sea, Arafura Sea, the Pacific and Indian Oceans. With hundreds of small and big islands, bays, and straits, the area has potential for marine fisheries development.

" President Director of PT Usaha Mina (Persero), Indonesia 
The fisheries of eastern Indonesia differ somewhat from those of western Indonesia. The differences are related to geographical conditions and economic development. The accessibility of east Indonesia is relatively difficult and it is less populated than the west. Hence considering numbers of local fish consumers, the west Indonesian re. gion has a bigger market. Being constrained by a smaller domestic market, the fishery in eastern Indonesia is outwardly directed to supply export markets. This direction determines the types of fishing technology employed. The major differences between eastern and western Indonesia fisheries are given in Table 1.

In terms of the numbers of fishery establishments (companies and households), the east is slightly bigger than the west. The numbers of fishers in east and west Indonesia are comparable. About $30 \%$ of the total of Indonesian full time fishers stay in eastern Indonesia. Since eastern Indonesia is less populated than the west, the distribution of fishery establishments and the number of fishers indicates that there are relatively more people in eastern Indonesia who rely on fishing for their living. This dependency on fishing may be explained by the fact that the east has more water than land. Consequently, more fishing fleets can operate in the east than in the west.

Although about $54 \%$ of the total fishing fleets are operating in eastern Indonesian waters, the size and type of the boats are less developed. Of the total non-motorised boats in Indonesia, fishers in the east own $68 \%$. The more modern the fishing boats, the less chance that they are owned by east Indonesian fishers. That is to say the fishery of east Indonesia is more traditional and smaller in scale than that in the west. Hence, al- though eastern Indonesia has more fishing fleets and broader waters, its fish landings are less than those of west Indonesia (Table 1).

The difference between eastern and western Indonesia may be seen from the availability of fish resources. Applying more powerful tools and using more accurate data, recent estimates show that the total MSY for Indonesian waters is 6.1 million tonnes per year (Table 2). Defining that the optimal rate of resource utilisation is $100 \%$ of MSY, it is estimated that some waters, especially the ones in west Indonesia, have been fully or over exploited. The resources in east Indonesian waters, on the other hand, are under exploited and therefore provide more opportunity for development (Table 3). Despite fish resources being available, the development of commercial fisheries in eastern Indonesia is not free from inherited and structural problems, particularly those of investment and marketing. Unlike in Java and other regions in west Indonesia where investors compete to get into the business because they are driven by the market, this not the case for remote and isolated areas of eastern Indonesia. The lack of supporting facilities and infrastructure as well as the same level of bank interest rate prevailing throughout the country, make investment in commercial fisheries in eastern Indonesia uncompetitive. There are ideas to bring fish landed in eastern Indonesia to the lucrative markets of west Indonesia. Yet, expensive transportation costs hinder the realisation of these ideas. Above all, fish deteriorate and spoil, so that bringing fresh fish from eastern to west Indonesia does not make economic sense if premium prices are small. As a result, in spite of having the natural resources, the development of commercial fisheries in eastern Indo. nesia cannot be accelerated.

Table 1. Difference between eastern and western Indonesian fisheries, 1985.

\begin{tabular}{|c|c|c|c|}
\hline Variables & Eastern & Western & Indonesia \\
\hline Fishery establishments (unit) & $226,183(0.53)$ & $199,598(0.47)$ & 425.781 \\
\hline Fishing fleet(number) & $213,648(0.54)$ & $182,541(0.46)$ & 396,185 \\
\hline Non-motorised boat (number) & $167.123(0.68)$ & $78,363(0) 32)$ & 245,486 \\
\hline Outboard engine vessel (number) & $29,107(0.33)$ & $58,642(0.67)$ & 87,749 \\
\hline Inboard engine vessel (number) & $17,414(0.28)$ & $45,536(0.72)$ & 62,950 \\
\hline Landings (tonnes) & $1,328,112(0.43)$ & $1,752,056(0.57)$ & $3,080,168$ \\
\hline Total fishers (head) & $823.269(0.44)$ & $1,026,975(0.56)$ & $1,850,244$ \\
\hline Full time fishers & $280,651(0.30)$ & $644,684(0.70)$ & 925,335 \\
\hline
\end{tabular}


Table 2. The MSY and utilization of Indonesian marine fish resources.

\begin{tabular}{lrcc}
\hline \multicolumn{1}{c}{ Species } & \multicolumn{1}{c}{$\begin{array}{c}\text { MSY } \\
\text { (ton) }\end{array}$} & $\begin{array}{c}\text { Production } \\
\mathbf{1 9 9 7} \text { (ton) }\end{array}$ & $\begin{array}{c}\text { Utilization } \\
\mathbf{1 9 9 7} \text { (ton) }\end{array}$ \\
\hline Demersal & $1,792,000$ & $1,113,000$ & 0.62 \\
Small Pelagic & $3,177,000$ & $1,415,800$ & 0.45 \\
Tuna & 152.000 & 199.000 & 1.31 \\
Skipjack & 374.000 & 191.000 & 0.51 \\
Tongkol & 205.000 & 186.486 & 0.91 \\
Tenggiri & 127.000 & 74.640 & 0.59 \\
Setuhuk & 19.000 & na & - \\
Layaran & 6.000 & na & - \\
Shark & 11.000 & na & - \\
Shrimp & 114.000 & 84.561 & 0.74 \\
Lobster & 5.000 & 2.021 & 0.40 \\
Coral fish & 76.000 & na & - \\
Squid & 22.000 & 26.216 & 1.19 \\
Ornamental fish & 60.000 & na & - \\
Unidentified & & 518.915 & - \\
\hline Total & $6,010,000$ & $3,810,999$ & 0.63 \\
\hline
\end{tabular}

Remarks: na = data are not available

Source: Nurhakim el al. (1998)

Table 3. The utilization level (100\% optimal) of marine fish resources in Indonesia, 1997.

\begin{tabular}{|c|c|c|c|c|c|c|c|}
\hline Waters & Shrimp & Demersal & $\begin{array}{c}\text { Small } \\
\text { pelagic }\end{array}$ & Tuna & Skipjack & Tenggiri & Tongkol \\
\hline Malaka Strait & 154 & 178 & 106 & - & - & - & - \\
\hline South China Sea & 114 & 30 & 23 & - & - & - & 0 \\
\hline Java Sea & 161 & 54 & 132 & - & - & 46 & 114 \\
\hline Flores Sea & 106 & 103 & 50 & 76 & 107 & 37 & 78 \\
\hline Banda Sea & na & 56 & 25 & 42 & 38 & 14 & 18 \\
\hline Maluku Sea & 68 & 76 & 46 & 64 & 34 & 7 & 63 \\
\hline Sulawesi Sea & 116 & 100 & 29 & 58 & 25 & 102 & 20 \\
\hline Arafura Sea & 98 & 93 & 4 & 52 & 70 & 26 & 7 \\
\hline Indian Ocean & 88 & 84 & 41 & 38 & 19 & 29 & 58 \\
\hline
\end{tabular}

Source: Nikijuluw (1!)!8)

The government of Indonesia has set up vari. ous fisheries development programs. Fisheries have been constantly promoted as a source of international earnings and a trigger for coastal rural development. In other words, what is expected from fisheries is not confined solely to fishing activities, but rather broader activities covering pro- cessing, marketing, and input provisions. So commercial fishing includes not only fishing, but also forward and backward linkage activities. To realise such fisheries business, resources should be made available. Otherwise business will cease, as resources are no longer available. Hence, in order to have a sustainable fisheries business, the 
availability of resources is vitally important. In other words, long-term profitable commercial fisheries only can be realised if fish resources are taken into consideration.

The following section will discuss the roles of Usaha Mina in developing small-scale commercial fisheries. By having an export orientation business that entails and requires good quality products, the landings of small-scale fishers can enter international markets. Being provided with mar. keting and input supplies helps fishers, who have little capital and little business management experience. They are guaranteed access to fishing grounds and the facilities provided by Usaha Mina. The collaboration between Usaha Mina and smallscale fishers has developed as a prototype of a local people-based fisheries industry relationship.

\section{THE EXPERIENCE OF USAHA MINA}

\section{Developing Collaborative Fishing with Small-scale Fishers}

Usaha Mina is a government-owned company, which was established in 1973. The main business of the company is tuna and skipjack fishing. The objective of the company is to carry out and support government economic development programs, especially those dealing with fisheries. To meet the objective, the scope of works of Usaha Mina includes fishing, fish processing and marketing, dockyard services and workshops for boat maintenance and repair, and provision of input factors.

For about 25 years, Usaha Mina has grown and constantly reoriented its activities to improve company performance. Reorientation programs include:

* Expanding from Sorong to new fishing grounds and operation bases in other parts of eastern Indonesia. The fishing grounds of the company's fleet are now throughout eastern Indonesian waters.

* Diversifying target fish away from only tuna and skipjack to other high value pelagic and demersal fish. It should be pointed out that diversification has taken place slowly, and that pole-and-line fishing remains the core activity. Consequently, skipjack and tuna are the dominant catch

* Diversifying the final products from frozen to semi-processed and finally processed fish.

* Applying new fishing strategies by installing fishaggregating devices (rumpon). The deployment of rumpon was an entry point to involve smallscale fishers in the production line of the company. It also created a new system of resource accessibility.

The reorientation was performed as a response to a new business environment and resource man. agement approach. Under the current arrange. ments of the national fisheries development pro. gram, management of fish resources is a serious question. Rational fisheries resource management is explicitly stipulated as an objective. Following this arrangement, it is important not only to catch more fish. but also to have more returns. There are various ways to come up with more returns, but sound resource management is very impor. tant. As explained earlier, only proper fish re. source management will sustain long term returns.

Usaha Mina is committed to develop smallscale fishers in eastern Indonesia. Partnership relationships between the company and smallscale fishers have been developed and practiced since 1985. Starting in Sorong, Irian Jaya, it has spread to other parts of Irian Jaya and covers some fishing bases in Maluku and Sulawesi. The success of the partnership relationship has become the main contribution of Usaha Mina production. The company that just focused on fishing by using its own pole-and-line vessels and crews now has a range of activities, which involve small-scale fishers. This collaboration allows the company to buy fish from small-scale fishers who use their own gear and vessels.

One of the missions undertaken by Usaha Mina is to empower small-scale fishers. From that perspective, collaboration with small-scale fishers is structured in such a way that an individual small. scale fisher may become a fishing entrepreneur. The empowerment of individual fishers is phased as follows:

1. The development of individual fishers to form a group of fishers. Individual fishers having technical capability are guided by Usaha Mina so that they can improve economically. The fishers are encouraged to form groups in order to gain economies of scale and be easily prepared to accept extension and guidance.

2 . The application of a cooperative management approach to develop fisher group institutions. The fisher groups are helped to understand and apply the principles of 
cooperative management as a preparation for the establishment of fisheries cooperatives.

3 . The development of fisher groups to form fisher cooperatives. As the groups can better apply cooperative management principle, the next step is to encourage the groups to form fisheries cooperatives. By Indonesian law, a fisheries cooperative is more powerful than just a fishers group. The cooperative has accessibility to banking credit and other government aid programs.

4. The development of outstanding cooperative members to become private fishers who have fishing assets and capital. The outstanding cooperative members are guided to establish their own fishing companies. Hence the new established companies can create operational systems by which other small-scale fishers may be involved. This development of outstanding cooperative members means that their membership of cooperatives are terminated.

Beside the above system, Usaha Mina also develops upstream and downstream partnerships with other companies, such as those running fish processing activities and dockyard services (Table 4). These relationships are established with the objective of controlling input factors used in fish. ing. A specific relationship is established for each partner, depending on shares and obligations.

Partnership in fishing activities relies on $\mathrm{mu}$ tual benefits that can be achieved by Usaha Mina and its partners. The target is to increase efficiency, shown by increases in fish landings pro-

Table 4. Keys to the success of collaborative arrangements between Usaha Mina and small-scale fishers.

\begin{tabular}{|c|c|c|c|}
\hline \multirow{3}{*}{ Keys to success } & \multicolumn{3}{|c|}{ Responsibilities } \\
\hline & \multirow{2}{*}{$\begin{array}{c}\text { Nucleus firm } \\
\text { PT. Usaha Mina }\end{array}$} & \multicolumn{2}{|c|}{ Plasma } \\
\hline & & Cooperative group & Individual fishers \\
\hline Boat Procurement & $\begin{array}{l}\text { Providing boat } \\
\text { technology, } \\
\text { Collaborating with } \\
\text { dockyard firm. }\end{array}$ & $\begin{array}{l}\text { Providing some financial } \\
\text { aid, screening fisher. } \\
\text { acting as boat credit } \\
\text { receiver. }\end{array}$ & $\begin{array}{l}\text { Be skilful and have } \\
\text { experience in boat } \\
\text { management. }\end{array}$ \\
\hline Operation of boat & $\begin{array}{l}\text { Providing } \\
\text { infrastructure, dock, } \\
\text { workshop, technicians, } \\
\text { license, supplies, and } \\
\text { insurance. }\end{array}$ & $\begin{array}{l}\text { Providing sailing license. } \\
\text { Crew supplies and } \\
\text { insurance. }\end{array}$ & $\begin{array}{l}\text { Guaranteeing the } \\
\text { readiness of boat and } \\
\text { crews. }\end{array}$ \\
\hline Boat productivity & $\begin{array}{l}\text { Guiding to fishing } \\
\text { ground, fishing } \\
\text { techniques, providing } \\
\text { carrier and processing } \\
\text { vessels. }\end{array}$ & $\begin{array}{l}\text { Improving crew } \\
\text { motivation, maintaining } \\
\text { crew balance and } \\
\text { composition, bolstering } \\
\text { fishing cooperation. }\end{array}$ & $\begin{array}{l}\text { Finding the best fishing } \\
\text { grounds, communicating } \\
\text { with operational } \\
\text { management. }\end{array}$ \\
\hline Production value & $\begin{array}{l}\text { Doing market research } \\
\text { and controlling quality. }\end{array}$ & $\begin{array}{l}\text { Determining selling price } \\
\text { to the nucleus, supplying } \\
\text { to local markets. }\end{array}$ & $\begin{array}{l}\text { Proper fish handling, } \\
\text { selling all fish to nucleus. }\end{array}$ \\
\hline $\begin{array}{l}\text { System } \\
\text { establishment }\end{array}$ & $\begin{array}{l}\text { Developing the } \\
\text { management of the } \\
\text { nucleus and plasma. } \\
\text { institutional } \\
\text { coordination, developing } \\
\text { the system. }\end{array}$ & $\begin{array}{l}\text { Applying cooperative } \\
\text { management approach to } \\
\text { fishers groups. }\end{array}$ & $\begin{array}{l}\text { Applying management } \\
\text { concept, providing } \\
\text { suggestions for the } \\
\text { improvement of } \\
\text { management. }\end{array}$ \\
\hline
\end{tabular}


cured by Usaha Mina. At the same time, benefits that can be derived by partner fishers are profitability and certainty of the business. In order to achieve benefits for both parties, they must work hand in hand. Usaha Mina bears all the operating costs and risks in the operations of fisher's boats. The fish price paid by Usaha Mina to fishers should be able to be used to cover the investment value of fishing boats and equipment within their economic: life. This model is has become known as the nucleus-small holders system (PIR system). To maintain this type of cooperation, all factors determining the success of fishing operations should be under the shared control of Usaha Mina as the nucleus of the company and the fishers as the plasma of the system.

To facilitate the growth of collaborative fishing between Usaha Mina and small-scale fishers, a link with dockyard and ship building companies was needed. This kind of link is needed also by the Dockyard Company if it wants to guarantee the market flow of its product. Based on this situation, a three party mutual collaboration between Usaha Mina, fishers and a dockyard company was established. This collaboration can help fishers expand their business as they now operate their own boats. The result of this collaboration for Usaha Mina is to have more fish. Boats provided by the Dockyard Company are credited to smallscale fishers without collateral. Management of fishing activities, marketing of the catch, as well as fish quality control is the responsibility of Usaha Mina. The fishers pay for the boats by instalment to the Dockyard Company. The amount of the instalment depends on the amount of fish landed and is deducted directly by Usaha Mina from the value of fish landings.

The type of boat procurement through this scheme is successful for the following reasons:

1. The payment for a boat by the fisher to the Dockyard Company depends on the amount of catch so that the risks of catch fluctuation are shared between fishers, Usaha Mina and the Dockyard Company.

2. The involvement of the Dockyard Company directly in fishing activities has prompted the company to provide good quality boats.

3. The credit provided by the Dockyard Company is without collateral and does not follow formal banking procedures. Credit is given by considering the reputation and achievements of individual fishers.
The development of collaboration between Usaha Mina and small-scale fishers is presented in Table 5. Currently, there are at least 16 fisher groups and cooperatives involved in the production line of Usaha Mina. The historical trend shows that every year; a new group or cooperative is established. Those who concentrate on fishing are not only individual fishers, groups or cooperatives, but also private companies. This development can be used to show that the responsibilities of Usaha Mina for the extension and guidance of small-scale fishers have been successful.

There are three partners that work in dockyard services and four partners which work in fish processing and marketing. The relationship with these seven companies shows that forward and backward-linked activities are crucial ones. The partner companies are both national and multinational firms. This paves the way for Usaha Mina to develop local and international marketing channels.

Table 6 shows that the-roles of small-scale partners have grown significantly in terms of sales, landings and fishing fleets. At the time the partnerships were established, landings of Usaha Mina's own fleets were about 10 times than its partner's. By 1987, the situation had reversed and landings of partner's fleets were about double the landings of Usaha Mina. In 1996, the role of partners in this matter reached seven times that of the main company. Table 6 also shows that sales increased tremendously from about $\mathrm{Rp} 3$ billion in 1985 to somewhat more than $R p 46$ billion in 1996.

\section{Emerging Problems Faced by Usaha Mina}

Usaha Mina's main objective is growth by letting its partners grow. In other words, mutual growth is the basis for increasing the future role and performance of Usaha Mina. However, some problems have occurred and are likely to affect the performance of the company, now and in the future. The problems are elucidated below:

1. Pole-and-line fishing as the core business of Usaha Mina has rapidly developed in the area. The policy of the central government to promote eastern Indonesian provinces attracts domestic and foreign investors to enter the fisheries business. These investors bring their bigger boats and sometimes operate better 
Table 5. The histori of business collaboration undertaken by Usaha Mina.

\begin{tabular}{|c|c|}
\hline Partners of Usaha Mina & History \\
\hline \multicolumn{2}{|l|}{ Fishing } \\
\hline Fishers Cooperative, Tunas Jaya, Sorong & $\begin{array}{l}\text { Fishers group } 1985 . \\
\text { Cooperative } 1992 .\end{array}$ \\
\hline Fishers Cooperative. Tunas Jaya, Bacan & $\begin{array}{l}\text { Fishers group } 1987 \\
\text { Cooperative } 1993\end{array}$ \\
\hline Fishers group, Tunas Jaya, Gorontalo & 1989 \\
\hline Fishers group. Tunas Jaya, Luwuk & 1990 \\
\hline Fishers group, Tunas Jaya, Fak-Fak & 1992 \\
\hline Fishers group, Serenia, Bacan & 1992 \\
\hline Fishers group, Laying, Bacan & 1993 \\
\hline Fishers group, Gancsko, Bacan & 1995 \\
\hline Fishers group, Tunas Jaya. Tual & 1995 \\
\hline Fishers group, Mina Bahari Bacan & 1996 \\
\hline Fishers group. Tunas Jaya. Bone & 1996 \\
\hline Fishers group. Tunas Jaya. Kajang & 1996 \\
\hline CV Lippopuna, Bacan & 1995 \\
\hline CV Safari, Bacan & 1996 \\
\hline PT Ramoi, Sorong & 1993 \\
\hline PT 'Tirta Khatulistiwa Farming, Sorong & 1996 \\
\hline \multicolumn{2}{|l|}{ Dockyard Facilities } \\
\hline P'T Karya Teknik Utama, Sorong & 1991. Supply 30 boats of $40-70 \mathrm{G} T$ \\
\hline PT Karya Cipta suana Sentose, Bacan & 1996. Supply 60 FRP boats of 10 GT \\
\hline P'T Mahkota, Gorontalo & 1996. Supply 100 FRP boxes \\
\hline \multicolumn{2}{|l|}{ Processing and Marketing } \\
\hline Aizac Co. Ltd/Mina Maluku Inc., Japan & 1993. Marketing of block sashimi, Bacan \\
\hline Trimarine Int., Japan & 1996. Tuna Processing (loins and GG). \\
\hline P'T Dharma Samudera, Kendari. & 1996, Demersa 1 Fish Processing. \\
\hline CV Ome, Sorong & 1995, Arabushi Processing. \\
\hline
\end{tabular}

facilities. At the same time, small-scale fishers have modernised their boats so that they can capitalise their profits or have access to subsidised government credit. Together with more fishing fleets operated by Usaha Mina (Table 6); the result has been a substantial increase in fishing effort that may be adversely affecting total landings.

2. As more pole-and line boats are operated. more live baitfish are required. The higher demand for live baitfish has prompted small-scale fishers to invest in the lift net fishery. Apart from being used as live baitfish, the production of lift nets is also demanded by local and export markets for human consumption. The competition between whether the fish are used as baitfish or human food cannot be avoided. In some areas, especially isolated ones, there are no other buyers other than pole-and-line fishers, but in many other places both type of buyers exist which drives up the price of baitfish. 
Table 6 Development of partnerships in PT. Usaha Mina.

\begin{tabular}{|c|c|c|c|c|c|c|c|}
\hline \multirow{4}{*}{ Year } & \multicolumn{7}{|c|}{$\begin{array}{r}\text { Business development } \\
\end{array}$} \\
\hline & \multirow{3}{*}{$\begin{array}{c}\text { Sales of } \\
\text { Usaha Mina } \\
\text { (Rp million) }\end{array}$} & \multicolumn{2}{|c|}{$\begin{array}{c}\begin{array}{c}\text { Fish landing } \\
\text { (tonnes) }\end{array} \\
\end{array}$} & \multicolumn{4}{|c|}{ Fleets } \\
\hline & & \multirow[b]{2}{*}{$\begin{array}{l}\text { Usaha } \\
\text { Mina }\end{array}$} & \multirow[b]{2}{*}{ Partners } & \multirow{2}{*}{$\begin{array}{l}\text { Usaha Mina } \\
\text { (>30 GT) }\end{array}$} & \multicolumn{3}{|c|}{ Partners } \\
\hline & & & & & $\begin{array}{l}\text { Small } \\
(<3 \text { GT })\end{array}$ & $\begin{array}{l}\text { Medium } \\
(3-30 \text { GT) }\end{array}$ & $\begin{array}{c}\text { Large } \\
(>30 \text { GT })\end{array}$ \\
\hline 1985 & 3,269 & 5,239 & 530 & 29 & 2 & 5 & 2 \\
\hline 1986 & 4,110 & 4,400 & 1,106 & 28 & 2 & 2 & 6 \\
\hline $198 i$ & 5,972 & 2,857 & 4,108 & 29 & 39 & 41 & 9 \\
\hline 1988 & 11,644 & 2,495 & 8,276 & 29 & 158 & 63 & 9 \\
\hline 1989 & 13,472 & 2,297 & 9,717 & 24 & 275 & 82 & 14 \\
\hline 1990 & 22,069 & 3,769 & 13,424 & 43 & 337 & 74 & 15 \\
\hline 1991 & 22,862 & 6,408 & 11,713 & 35 & 389 & 78 & 23 \\
\hline 1992 & 24,897 & 4,058 & 13,424 & 30 & 261 & 79 & 23 \\
\hline 1993 & 30,375 & 3,527 & 14,436 & 27 & 238 & 81 & 26 \\
\hline 1994 & 33,239 & 2,163 & 11,880 & 27 & 211 & 91 & 27 \\
\hline 1996 & 37,852 & 2,702 & 13,005 & 27 & 214 & 71 & 30 \\
\hline 1996 & 46.150 & 2,153 & 15,041 & 27 & 156 & 60 & 35 \\
\hline
\end{tabular}

3. Usaha Mina is trying to cope with these problems by establishing groups of lift net fishers. In some places, the group is part of a fisheries cooperative. The collaboration with the group of fishers can guarantee pole-and-line fishers enough baitfish and at the same time pay a better price to the lift net fishers.

4. The development of pole-and-line fisheries accompanied by tight competition for baitfish has lowered the landings-baitfish ratio of poleand-line fishers. In other words, to get the same amount of landings, more baitfish have to be used.

5. Tuna fishing on the high seas apparently affects pole-and-line fishing in inshore waters. The uncontrolled fishing in the EEZ by small-mesh purse seiners equipped with fish-aggregating devices reduces the availability of fish in territorial waters that are the fishing grounds of small-scale fishers. The placement of fish aggregating devices in the migration paths and the gateways of tuna and skipjack further curtails the availability of the fish in the inshore and territorial waters of Indonesia.

\section{CALL FOR BE'T'TER FISHERIES MANAGE-} MEN'T

As discussed previously, fishery management entails interrelationships between resource management and business management. Neither of which can be left behind without affecting the other. So to have better pole-and-line fishery performance, both these aspects of fishery management must be considered together. Because baitfish are a very important input to pole-and. line fishing, the management of the baitfish resource should be linked to the management of poleand-line fishing. So far what has prevailed is the exclusiveness of both fisheries. Each has its own strategy and fishers form separate groups or cooperatives so that in the field there are group of pole-and-line fishers and group of lift net fishers. The two groups indeed collaborate, but this does not mean that transactions between the groups are coordinated. For instance, the catch of the lift nets that are needed by pole-and-liners may be sold to other buyers, especially the traders and processors of salted fish. 
If pole line and lift net fishers can be organised into the same group or cooperative then transactions between fishers is conducted within the group. The experience of Usaha Mina shows that if the lift net becomes a component of pole-and line fishing, the supply of baitfish is not a serious problem. The price of baitfish may be set at the level where all are satisfied. The payment to lift net fishers may be arranged to be a part of the selling price of the catch of pole-and-liners.

Making the lift net fishery a component of poleand-line fishing may bring about several consequences. First, all pole-and-line-fishing companies should have their own lift net. This will radically change the existing situation where some companies just concentrate on fishing and never invest in the supply of baitfish. Such companies normally go around to find available baitfish and offer higher prices to lift net fishers who were established by or have become a component of other pole-and-line fishing companies. Of course they can offer higher prices for baitfish as they have not paid the investment and management costs of a lift net.

The second consequence is that there is a possibility of increasing the number of lift net fishers, which eventually may affect the long-term availability of resources. To prevent the decline of the baitfish resource, its management must be addressed by managers (government). Two main aspects that should be considered by the manag. ers are: (1) to provide opportunities for local traditional lift net fishers and (2) to determine rational amounts of allowable baitfish catch. The allowable catch should be further broken down in terms the amount of gear or fishing effort.

The high demand for baitfish may encourage fishers to increase their fishing effort. Without management of the resource, fishers may enlarge their gear, expand to new fishing grounds, or prolong fishing hours. At the same time, outsiders may look at the situation as an opportunity to invest. Coupled with the increasing demand for the catch of lift nets for human consumption, the fishing effort may substantially increase. This increase of fishing effort may devastate existing traditional systems such as territorial use rights and the property rights of local fishers.

The call for better resource management also applies to tuna and skipjack resources. Intensive tuna purse seine fishing in EEZ waters causes a declining catch of skipjack in pole-and-line fishing in inshore and territorial waters. For instance, it can be seen in Table 6 that the total landings of Usaha Mina peaked in early 1990s. Thenceforth. it was difficult to reach the same level of landings. Field observations also indicate that smallscale fishers face a declining catch that forces them out of fishing.

There is also evidence that large-scale tuna and skipjack fishing do not operate only in the EEZ. but also in the territorial and inshore waters which are designated for small-scale fishers. The entry of large-scale fishers who are often supported by multinational companies or wrapped in nepotism with official connections make their businesses are so strong that the small-scale fishers and the previously existing companies suffer both physical and economic set backs.

The management of tuna and skipjack resources, therefore, should be appropriately addressed in order to sustain the life of small-scale fishers and national pole-and-line fishing companies. The fisheries managers in this concern are confronted with the choices of improving and protecting small-scale fishers or promoting large-scale investors who may run efficient business, but have limited trickle down effects. It should be kept in mind that the choices have implications for lift net fisheries.

\section{CO-MANAGEMENT OF POLE-AND-LINE FISHING}

Usaha Mina has developed co-management in pole-and-line fishing. Co-management refers to sharing of responsibilities between Usaha Mina and fishers in the management of fisheries resources. Certainly, this co-management should be carried out at local level, covering the waters in which fishing activities are conducted. More specifically, co-management is applied in the waters around rumpon or in the areas that are still affected by the existence of rumpon.

Before collaboration was embodied, individual fishers fished in all coastal waters, wherever they liked. Some fishers had gear and others just worked as boat crews. The gear and boats owned by many fishers were traditional in nature, being able to catch only in coastal waters. Under these circumstances, landings were small and volatile because fishing was highly determined by season and the capacity of boats. Generally, the landings 
were sold locally. Due to limited local demand, fish prices were low and consequently did not encourage fishers to produce more. After all, fishers were considered poor

With the collaboration developed by Usaha Mina, all the aforementioned shortcomings were overcome. The partnership brought about a new business environment as whatever the landings of small fishers: Usaha Mina buys them as the nucleus firm. This results in bigger fisher returns and earnings. The evaluation done by either Usaha Mina or government research institutes showed that fishers income increased several times, leading to better social and economic conditions (Nikijuluw et al., 1994).

The partnership opened the chance for fishers to control fishing grounds. The waters around rumpons are designated for fishers who work under partnership arrangements. In this regard, other fishers particularly those using large-scale boats and gears are not allowed to fish in the waters around the rumpon. Indeed it is not an easy task to patrol the rumpon. However, any time fishers are out fishing. they can recognise whether those operating their boats by the rumpon are their fellows or other fishers. That is to say that deploy. ment of rumpons creates new approaches to resource management in which rights to access or to withdraw fish resources are established.

The responsibility of Usaha Mina is to bear all costs related to instalment and repair of rumpon. The responsibilities of fishers are to use, take care. and patrol the rumpon. The benefit derived by fishers is that they can achieve efficient fishing operations as fuel costs decline and catch increases. The benefit for Usaha Mina is to have more fish supplied by fishers. The availability of rumpons has changed fishing strategies. Hunting or sailing around to find fishing grounds have been replaced by directing the boat to rumpons. In other words, fishing grounds were changed from "anywhere" to certain places. As a result, many areas that do not have rumpons tend to be free from fishing activities. While fishing intensity increases in the waters around rumpons, fishing effort declines in other areas. The placement of rumpons therefore affects the availability and sustainability of fish If a rumpon is placed in spawning or nursery areas, young and immature fish may be caught. Consequently recruitment fails and fish stock declines. The same thing happens if a rumpon is placed in spawning grounds. To avoid these possibilities, rumpons deployed by Usaha Mina are not placed in such areas.

\section{CONCLUDING REMARKS}

An important question that should be answered in this workshop is whether there is more investment opportunities in commercial fishing in eastern Indonesia. Looked at from the perspective of the target fish resources, one may say that there are opportunities. However, considering local economic factors, the chance and priority given to small-scale fishers, and the rights of local fishers to fish, which are nested in customary laws, and distribution and trickle down processes, one may argue that the development of large-scale commercial fishing in eastern Indonesia is no longer ap. propriate. If so, what is the strategy and how can the available resources can be optimally utilised?

The experience of Usaha Mina and many small farmers in the area provides evidence that fishery development in eastern Indonesia should be based on full participation by small fishers. However, to let the small-fishers run their businesses by them. selves is not the right strategy, as they face difficulties in marketing, input supplies, and boat and gear procurement. Therefore, collaborative fishing which is based on the availability and sustainability of the resources and capability of fishers should be further promoted. With the guidance of government, proper, efficient, and fair collaborative schemes between national companies and small fishers can be defined. The government should also determine the path of fisheries development by setting up a long-term strategy. On the basis of such a strategy, fishing companies can further define their business path and be guided to long term investment planning.

\section{REFERENCES}

Bailey, C.. Dwiponggo, A., Marahudin, F. 1987. Indonesian marine capture fisheries. ICLARM Studies Rov. 10:1-196.

Gordon, H.S. 1954. The economic theory of a common property resource: the fishery. J. Pol. Eron. 62(2): 124-142

Nikijuluw, V.P.H., Naamin, N. and Sarjana. 1994. The Evolution of NES system in tuna and skipjack fisheries in Indonesia: Concept, Institutional, and Financial Aspects. In Socio-economic Issues in Coastal Fisheries Management. Proceedings of the IPFC Symposium. RAPA Publication 1994/8. 406-415 
Nikijuluw. V.P.H. 1998. Pengembangan Ekonomi Kawasan Pesisir melalui Perikanan Tangkap yang Bertanggung Jawab. Makalah pada Pelatihan Intensif Pertanian. Yayasan Mitra Pembangunan Desa, Cianjur 6 Juli 1998.

Nikijuluw, V.P.H. 1998. Kemampuan Sektor Perikanan dalam Menerima Tenaga Kerja yang Terpuruk Akibat Krisis Moneter: Suatu Telaah Teoritis. Makalah dibawakan pada Seminar Rutin Puslit Sosial Ekonomi Pertanian, 24 April 1998.

Nurhakim, S., Uktolseja, J.C.B., Badrudin, dan Merta. I.G.S. 1998. Potensi, Penyebaran, dan Pemanfaatan Sumber Daya Ikan di Indonesia. Balai Penelitian Perikanan Laut, Jakarta 29 pp.

Panayotou, T. 1985 Small-scale Fisheries in Asiat So(io-economic Analysis and Policy. IDRC. Ottawa. $283 \mathrm{pp}$.

Schaefer, M.B. 1957. Some considerations of population dynamics and economics in relation to the management of the commercial marine fisheries. J. Fish. Res. Bd. Can. 14: 669-681.

Soepanto. 1989. Development of Tuna and Skipjack Fisheries under the Nucleus Estate Payaos System, PT Usaha Mina (Persero). Paper Presented at the Third Southeast Asian Tuna Conference, Denpasar Bali, Indonesia, 22-24 August 1989.

Soepanto. 1997. Fishing and Resource Management Partnerships Undertaken By PT Usaha Mina (Persero). Indonesia. Paper Presented at the Seminar on "Smart Partnership for Sustainability in the Fishing Industry" 26-28 November 1997. Ferringi Hotel, Penang, Malaysia.

Yahaya, J. 1994. Fish-Aggregating Device (FAD) and community-based fisheries management in Malaysia. In Socio-economic Issues in Coastal Fisheries Management. Proceedings of the IPFC Symposium. RAPA Publication 1994/8, 315-326. 